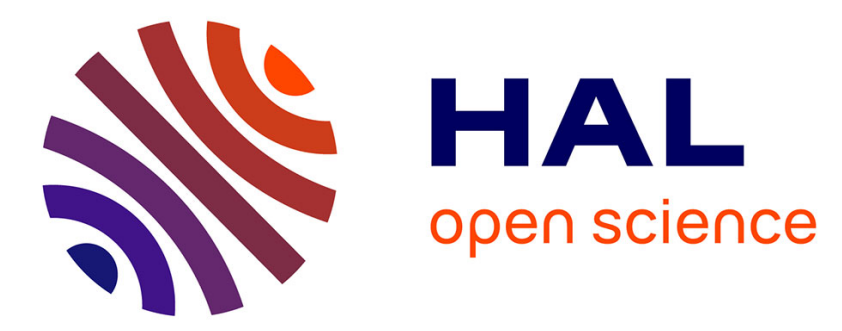

\title{
Scanning and Energy Dispersive EXAFS Studies of Nickel Alkene Oligomerisation Catalysts
}

\author{
J. Corker, A. Dent, J. Evans, M. Hagelstein, V. Kambhampati
}

\section{To cite this version:}

J. Corker, A. Dent, J. Evans, M. Hagelstein, V. Kambhampati. Scanning and Energy Dispersive EXAFS Studies of Nickel Alkene Oligomerisation Catalysts. Journal de Physique IV Proceedings, 1997, 7 (C2), pp.C2-879-C2-881. 10.1051/jp4:1997264 . jpa-00255347

\section{HAL Id: jpa-00255347 https://hal.science/jpa-00255347}

Submitted on 1 Jan 1997

HAL is a multi-disciplinary open access archive for the deposit and dissemination of scientific research documents, whether they are published or not. The documents may come from teaching and research institutions in France or abroad, or from public or private research centers.
L'archive ouverte pluridisciplinaire HAL, est destinée au dépôt et à la diffusion de documents scientifiques de niveau recherche, publiés ou non, émanant des établissements d'enseignement et de recherche français ou étrangers, des laboratoires publics ou privés. 


\title{
Scanning and Energy Dispersive EXAFS Studies of Nickel Alkene Oligomerisation Catalysts
}

\author{
J.M. Corker, A.J. Dent*, J. Evans, M. Hagelstein** and V.L. Kambhampati \\ Department Chemistry, University of Southampton, Highfield, Southampton SO17 1BJ, UK \\ * Daresbury Laboratory, Warrington WA4 4AD, UK \\ ** European Synchrotron Radiation Facility, BP. 220, 38043 Grenoble cedex, France
}

\begin{abstract}
In situ EDE and scanning EXAFS studies of homogeneous alkene oligomerisation catalysts are reported. EDE spectra were acquired either on Station 9.3 at the SRS Daresbury Laboratory using a bent $\mathrm{Si}(220)$ crystal monochromator (Ni and $\mathrm{Br}$ K-edges) or on ID24 at the ESRF using a Si(111) monochromator in a Bragg geometry (Ni K-edge). The catalysts studied were derived from mixtures of $\mathrm{Ni}(\mathrm{acac})_{2}$ ( $\mathrm{acac}=2,4$-pentanedionato) and $\mathrm{AlEt}_{2}(\mathrm{OEt})$ or $\mathrm{NiX}_{2}\left(\mathrm{PEt}_{3}\right)_{2}(\mathrm{X}=\mathrm{Cl}, \mathrm{Br})$ and $\mathrm{AlEt}_{3}$. For Ni(acac) $)_{2} / \mathrm{AlEt}_{2}(\mathrm{OEt}), \mathrm{Ni} \mathrm{K}$-edge EDE is consistent with a mean structure similar in nature to trimeric $\mathrm{Ni}(\mathrm{acac})_{2}$ but with partial substitution of acac ligands by alkene and alkyl groups. At $25^{\circ} \mathrm{C}$, further breakdown of the trimer occurs to give alkylated monomeric nickel species. For $\mathrm{NiCl}_{2}\left(\mathrm{PEt}_{3}\right)_{2} / \mathrm{AlEt}_{3}$, low temperature $\mathrm{Ni} \mathrm{K}$-edge EDE has been used to monitor alkylation of the $\mathrm{Ni}$ centre, and for ambient temperature mixtures of $\mathrm{NiBr}_{2}\left(\mathrm{PEt}_{3}\right)_{2} / \mathrm{AlEt}_{3}, \mathrm{Br} \mathrm{K}$-edge EDE data shows complete loss of $\mathrm{Br}$ from the metal centre occurring within minutes of adding AlEt3. Instrumental difficulties (detector and beamline setup) at the current time prevent acquisition of analysable EXAFS in a timescale faster than 0.1-10 s for these types of systems.
\end{abstract}

\section{INTRODUCTION}

The oligomerisation of $\mathrm{C}_{3}$ - $\mathrm{C}_{5} \alpha$-olefins for the production of $\mathrm{C}_{6}-\mathrm{C}_{18}$ plasticiser and detergent range olefins is an important industrial operation. The activation of nickel (usually phosphine) complexes in solution by alkyl aluminium reagents is the preferred route to the formation of alkene oligomerisation catalysts but such systems are often extremely active even at low temperatures making them difficult to study by standard techniques. We have shown previously that the activation of nickel complexes can be monitored by X-ray absorption spectroscopy (XAS): for example, in the case of $\mathrm{NiX}_{2}\left(\mathrm{PR}_{3}\right)_{2}(\mathrm{X}=\mathrm{Cl}, \mathrm{Br} ; \mathrm{R}$ $=$ alkyl) systems, we have shown that Ni..Al interactions (via alkyl bridges) occur in solution [1]: However, conventional scanning EXAFS experiments on dilute catalyst solutions require lengthy acquisition times and averaging of several spectra. Continuing improvements in energy dipersive EXAFS (EDE) techniques have indicated that this technique could be appropriate to these nickel systems. We have therefore begun a programme of work to test the applicability of EDE and learn more about the transmetallation process. We report here the first results of $\mathrm{Ni}$ and $\mathrm{Br} \mathrm{K}$-edge $\mathrm{EDE}$ studies on oligomerisation catalysts derived from $\mathrm{Ni}(\mathrm{acac})_{2} / \mathrm{AlEt}_{2}(\mathrm{OEt})(\mathrm{acac}=2,4$-pentanedionato $)$ and $\mathrm{NiX} \mathrm{X}_{2}\left(\mathrm{PEt}_{3}\right)_{2} / \mathrm{AlEt}_{3}$.

\section{EXPERIMENTAL}

EDE measurements were carried out using modified versions of a low temperature cell [2] fitted with a pair of syringe drivers to provide either a continuous or interrupted flow mixing, or alternatively with a modified HiTech Scientific SFA20 stopped flow apparatus. Both systems can be operated remotely from outside the X-ray hutch. Spectra (Ni and Br K-edges) were acquired either on Station 9.3 at the SRS Daresbury Laboratory using a bent Si(220) crystal monochromator or on ID24 at the ESRF (Ni K-edge) using a Si(111) monochromator in a Bragg geometry. The detector systems comprised either a 512 element (Reticon) linear photodiode array (PDA) or 1024 element (Hammamatsu) PDA running with a minimum readout time of $2 \mathrm{~ms}$ and controlled by a VM-based system (Daresbury) or a Tomson $512 \times 512$ element CCD camera operating in a PDA emulation mode with $10 \mathrm{~ms}$ readout time (ESRF). Background subtracted EXAFS data were obtained using the programme PAXAS [3]; spherical wave curve fitting analyses by least squares refinement of non-Fourier filtered $\mathbf{k}^{3}$-weighted data were carried out in EXCURVE, using Von-Barth ground state potentials and Hedin-Lundqvist exchange potentials [4].

\section{RESULTS AND DISCUSSION}

\subsection{Ni K-edge EDE of Ni(acac)/ $/ \mathrm{AlEt}_{2}(\mathrm{OEt}) / \mathrm{hex}$-1-ene in toluene}

Scanning EXAFS measurements [5] have shown that, in the presence of hexene, the predominant species existing in an inactivate solution of $\mathrm{Ni}(\mathrm{acac})_{2}$ and $\mathrm{AlEt}_{2}(\mathrm{OEt})$ in toluene at $-70^{\circ} \mathrm{C}$ is trimeric $\mathrm{Ni}(\mathrm{acac})_{2}(5.6 \mathrm{Ni}-\mathrm{O}$ bonds at $1.97 \AA$ and 0.8 
Ni..Ni bonds at $2.82 \AA$ ). Subsequent heating to $c a .5^{\circ} \mathrm{C}$ results in the formation of an active solution containing monomeric nickel species with acac and alkyl/alkene ligands ( $2.0 \mathrm{Ni}-\mathrm{O}$ bonds at $1.92 \AA$ and $3.1 \mathrm{Ni}-\mathrm{C}$ bonds at $2.03 \AA$ ). We have now begun to investigate this system using EDE. Analysis of Ni K-edge EDE data recorded at Daresbury in $14.5 \mathrm{~s}$ at $0^{\circ} \mathrm{C}(4.75$ min after the addition of $\mathrm{Ni}(\mathrm{acac})_{2}$ and hexene to $\mathrm{AlEt}_{2}(\mathrm{OEt})$ using a simple syringe driver cell set-up) showed a reduction in the Ni-O coordination number (4.4 $\mathrm{O}$ at $1.97 \AA)$, but maintenance of a Ni..Ni shell (1.3 Ni at $3.09 \AA$ ), and in addition, a new shell of $c a .2 .5$ carbons was identified at $2.16 \AA$. Thus EDE has enabled us to identify an intermediate of a similar nature to the trimeric catalyst precursor, but with partial substitution of the acac groups by alkene and alkyl ligands [5].

Further investigations of this reaction were carried out at the ESRF using a stopped flow cell set-up, affording faster (ca. $5 \mathrm{~ms}$ ) and more homogeneous reagent mixing. The cell was initially flushed through with $\mathrm{Ni}(\mathrm{acac})_{2} / \mathrm{AlEt}_{2}(\mathrm{OEt}) /$ hexene solution at ambient temperature and the energy dispersive X-ray absorption spectra recorded were found to be very similar to that observed from scanning measurements, indicating the presence of the monomeric alkylated acac (or product) species. Figure 1 shows the series of XAS spectra obtained at $6 \mathrm{~s}$ intervals (each spectrum $50 \mathrm{~ms}$ int. time; 100 scans averaged) after the injection of $\mathrm{AlEt}_{2}(\mathrm{OEt})$. Changes in the XANES are apparent immediately on injection of the aluminium reagent: the pre-edge feature, which is present in the initial product spectrum (spectrum a) has disappeared and the white line feature has increased in sharpness and intensity (spectrum b). As the reaction proceeds, the intensity of the white line feature reduces considerably and growth of the pre-edge feature (characteristic of the product) is also observed. Analysis of various sequences of EDE (Figure 1) show that the extent of reaction is greater at higher Al:Ni ratios (and temperatures) and suggests that the approach to the initial equilibrium is rapid (within $40 \mathrm{~s}$ ). The quality of data, however, is not sufficient to enable full EXAFS analysis to be carried out: instrumental difficulties (both detector and beamline set-up) appear to be the limiting factors.
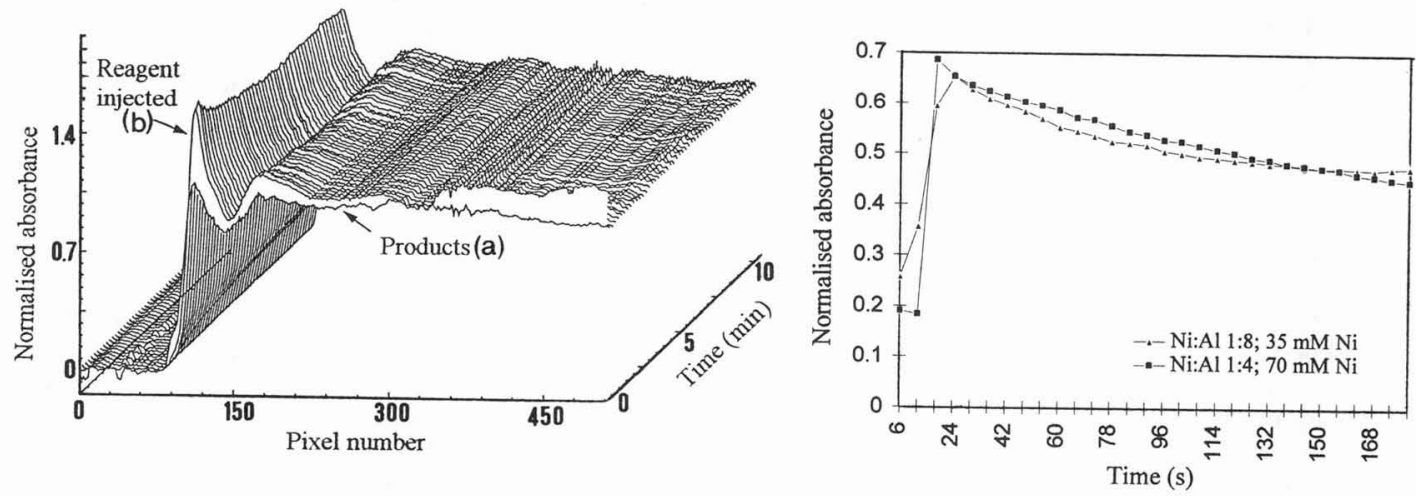

Figure 1: (i) Ni K-edge EDE of Ni(acac) $/ \mathrm{AlEt}_{2}(\mathrm{OEt}) / \mathrm{hex}-1$-ene $\left(35 \mathrm{mM} \mathrm{Ni}\right.$; Ni:Al 1:8) in toluene at $25^{\circ} \mathrm{C}$ recorded using a stopped flow sampling system, and (ii) normalised absorbance (white line feature) versus time for various Ni:Al ratios.

\section{2 $\mathrm{Ni}$ and $\mathrm{Br} \mathrm{K}$-edge EDE of $\mathrm{NiX}_{2}\left(\mathrm{PEt}_{3}\right)_{2} / \mathrm{AlEt}_{3}$ in p-nuorotoluene}

Scanning EXAFS experiments on low temperature solutions of $\mathrm{NiCl}_{2}\left(\mathrm{PEt}_{3}\right)_{2}$ and $\mathrm{AlEt}_{3}$ (or $\mathrm{Al}_{2} \mathrm{Me}_{3} \mathrm{Cl}_{3}$ ) have revealed the presence of Ni-C-Al interactions ( $2.2 \mathrm{Ni}-\mathrm{C}$ at $1.93 \AA, 2.1 \mathrm{Ni}-\mathrm{P}$ at $2.20 \AA$ and $1.5 \mathrm{Ni} . \mathrm{Al}$ at $2.98 \AA$ ) and we proposed that the $\mathrm{Ni}$.Al interaction may be one stabilising factor for the $\mathrm{Ni}^{\mathrm{iI}}$ organometallic species, possibly retarding $\beta$-hydride or reductive elimination to afford metal [1]. Our ${ }^{31} \mathrm{P}$ NMR studies [1,2] however have indicated the existence of several species and isomers in solution thus it seemed appropriate to try to study this equilibrium system by the more rapid technique of EDE. Our preliminary Ni K-edge EDE results (Figure 2) on a solution of $\mathrm{NiCl}_{2}\left(\mathrm{PEt}_{3}\right)_{2} / \mathrm{AlEt}_{3}$ at $-2^{\circ} \mathrm{C}(800 \mathrm{~ms}$ int. time; 1000 scans averaged) are consistent with but subtly different to those derived from scanning EXAFS measurements (spectra typically acquired over $2-3$ hours): $1.2 \mathrm{Ni}-\mathrm{C}$ at $1.99 \AA, 2.4 \mathrm{Ni}-\mathrm{P}$ at $2.24 \AA$ and $1.3 \mathrm{Ni} . \mathrm{Al}$ at $3.28 \AA$ (Table 1). Notably, the Ni..Al distance is longer in the EDE case, suggesting the existence of a species with a much weaker Ni-C-Al interaction.

We have also performed EDE experiments at the $\mathrm{Br} \mathrm{K}$-edge on ambient temperature mixtures of $\mathrm{NiBr}_{2}\left(\mathrm{PEt}_{3}\right)_{2}$ and $\mathrm{AlEt}_{3}$ (Table 2). Analysis of various EDE sequences indicate that complete loss of bromine from the nickel centre occurs within a few minutes after the addition of $\mathrm{AlEt}_{3}$, the $\mathrm{Br}$ K-edge EXAFS (60 ms int. time; 4000 scans averaged) being best fitted by two shells of aluminium atoms at 2.22 and $2.43 \AA$, suggesting the formation of an aluminium bromide type species.

\section{CONCLUSIONS}

From our EDE experiments we have been able to identify solution species which are not observed in conventional EXAFS experiments and we can conclude that discussions of the mechanisms of alkene oligomerisation should include reversible transmetallation processes. More importantly these results show that EDE can provide good quality EXAFS data in 
timescales of the order 0.1-10 s at present time. With continuing improvements in detector technology, however, it should be possible to obtain analysable EXAFS on complex systems in the sub ms timescale.

Table 1: Ni K-edge EDE results for $\mathrm{NiCl}_{2}\left(\mathrm{PEt}_{3}\right)_{2} / \mathrm{AlEt}_{3} / p$-fluorotoluene at $-2^{\circ} \mathrm{C}(70 \mathrm{mM} \mathrm{Ni} ; \mathrm{Ni}: \mathrm{Al}=$ 1:2.5). Numbers in parentheses are statistical errors generated in EXCURVE.

\begin{tabular}{llllll}
\hline Shell & $\begin{array}{l}\text { Coordination } \\
\text { number }\end{array}$ & $\mathrm{R} / \AA$ & $2 \sigma^{2} / \AA^{2}$ & $\begin{array}{l}\text { R-factor/ } \\
\%\end{array}$ & $\mathrm{E}_{\mathrm{F}} / \mathrm{eV}$ \\
\hline $\mathrm{C}$ & $1.2(2)$ & $1.99(1)$ & $0.009(2)$ & 29.7 & -2.8 \\
$\mathrm{P}$ & $2.4(1)$ & $2.237(4)$ & $0.0164(8)$ & & \\
$\mathrm{Al}$ & $1.3(2)$ & $3.28(2)$ & $0.038(6)$ & & \\
\hline
\end{tabular}

Table 2: $\mathrm{Br}$ K-edge EDE results for $\mathrm{NiBr}_{2}\left(\mathrm{PEt}_{3}\right)_{2}$ and $\mathrm{NiBr}_{2}\left(\mathrm{PEt}_{3}\right)_{2} / \mathrm{AlEt}_{3}$ in $p$-fluorotoluene at $25^{\circ} \mathrm{C}$ $(140 \mathrm{mM} \mathrm{Ni} ; \mathrm{Br}: \mathrm{Al}=1: 3)$. Numbers in parentheses are statistical errors generated in EXCURVE.

\begin{tabular}{llllll}
\hline Shell & $\begin{array}{l}\text { Coordination } \\
\text { number }\end{array}$ & $\mathrm{R} / \AA$ & $2 \sigma^{2} / \AA^{2}$ & $\begin{array}{l}\text { R-factor/ } \\
\%\end{array}$ & $\mathrm{E}_{\mathrm{F}} / \mathrm{eV}$ \\
\hline $\mathrm{NiBr}_{2}\left(\mathrm{PEt}_{3}\right)_{2}$ & & & & & \\
$\mathrm{Ni}$ & $1.02(3)$ & $2.291(3)$ & $0.0049(3)$ & 26.6 & -6.5 \\
$\mathrm{P}$ & $1.8(3)$ & $3.19(2)$ & $0.025(3)$ & & \\
$\mathrm{Br}$ & $1.0(2)$ & $4.44(1)$ & $0.038(6)$ & & \\
$\mathrm{NiBr}_{2}\left(\mathrm{PEt}_{3}\right)_{2} / \mathrm{AlEt}_{3}$ & $1.5(1)$ & $2.221(7)$ & $0.0125(9)$ & 39.5 & 6.2 \\
$\mathrm{Al}$ & $1.4(1)$ & $2.435(7)$ & $0.0061(7)$ & & \\
$\mathrm{Al}$ & & & & & \\
\hline
\end{tabular}
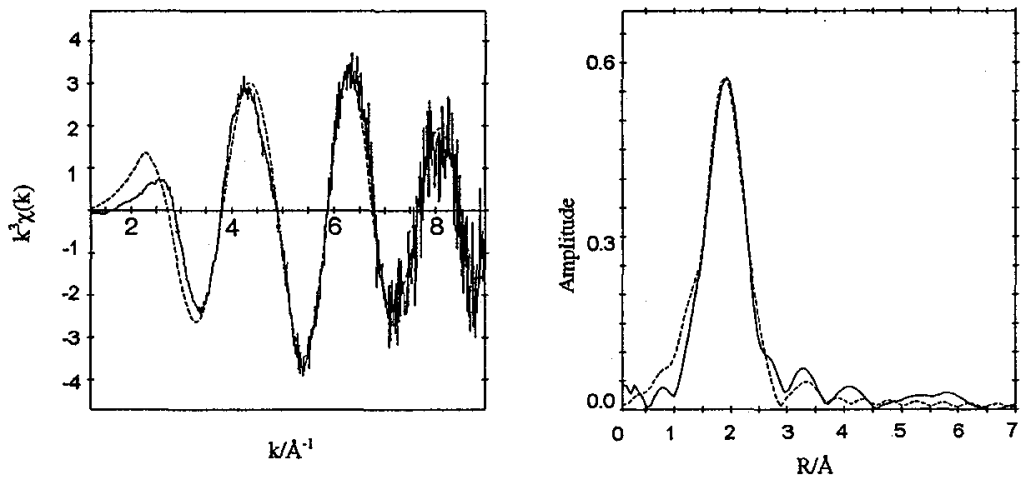

Figure 2: Ni K-edge EDE and Fourier transform (phase-shift corrected for carbon) of $\mathrm{NiCl}_{2}\left(\mathrm{PEt}_{3}\right)_{2}$ and $\mathrm{AlEt}_{3}$ in $p$-fluorotoluene at $-2^{\circ} \mathrm{C}(70 \mathrm{mM} \mathrm{Ni} ; \mathrm{Al}: \mathrm{Ni}=1: 2.5) .(\mathrm{Exp}$, and (-) spherical wave theory.

\section{Acknowledgements}

We are grateful to G. Salvini, D. Bogg, R.C. Farrow, and C.A. Ramsdale (Daresbury Laboratory), A. San Miguel and H. Müller (ESRF), HiTech Scientific for construction of the stopped flow apparatus, A.F. Masters, D.N. McLeod, and M. Conyngham (University of Sidney), the SERC and BP for a CASE award (J.M.C), the EPSRC and BP Chemicals also for a CASE award (V.L.K.), and the Royal Society for a research grant.

\section{References}

[1] Corker J.M. and Evans J., J. Chem. Soc., Chem. Commun. (1991) 1104-1106.

[2] Andrews P., Corker J.M., Evans J. and Webster M., J. Chem. Soc., Dalton Trans. (1994) 1337-1347.

[3] Binsted N., PAXAS Program for the analysis of X-ray absorption spectra, University of Southampton, UK (1988).

[4] Gurman S.J., Binsted N. and Ross I., J. Phys. C 17 (1984) 143-151; 19 (1986) 1845-1861.

[5] Bogg D., Conyngham M., Corker J.M., Dent A.J., Evans J., Farrow R.C., Kambhampati V.L., Masters A.F., McLeod D.N., Ramsdale C.A. and Salvini G., J. Chem. Soc., Chem. Commun. (1996) 647-648. 